\title{
COMPARATIVE CONCEPTUAL PERSPECTIVES ON IDENTITY BORDERS IN THE REPUBLIC OF MOLDOVA
}

\author{
Mircea BRIE, PhD Professor \\ Departament of International Relations and European Studies, \\ University of Oradea \\ Oradea/Romania
}

\begin{abstract}
The identity, be it that of an individual, a group or a community, can generate convergence, but also divergence in relation to the other. The other, dichotomous, acquires the expression of the "beyond"; beyond what is specific to one, to one's identity. A frontier, be it symbolic or ideological, can thus be identified around identity constructions. Central and Eastern Europe does not only make no exception to this rule, but, in our assertion, it is the space that imposes, perhaps most in Europe, such identity borders.

Methodologically, the focus of our analysis lies primarily on the identity boundaries generated by the specific ethno-religious, linguistic or cultural, but also by the nature of the mental specific to the area. This paper develops in a new methodological construction ideas and synthetic research contained in a previous paper on identity as a border in the space of Central and Eastern Europe.

For the purpose of a conceptual clarification and to respond to the methodological desideratum already announced, this paper makes comparative references to the case of the states of Northern Macedonia, Bosnia and Herzegovina and Montenegro or to the case of the Albanians in the Balkans. At a comparative level, the reality of identity cleavages, which oftenly takes the shape of borders, is similar in the Republic of Moldova and in the Balkans. However, a particular note given by the context is kept, namely the specificity
\end{abstract}


and the geopolitics of the former Soviet space in relation to the former Yugoslav one.

Identity dilemmas and controversies in the Republic of Moldova, as well as others in Central and Eastern Europe, are determined / fueled by the geopolitical interests of some states / powers that have used them to expand or maintain influences. Here, the boundaries of identity took the form of ideological or symbolic boundaries.

\section{Keywords}

Border; ethnicity; ethno-national identity; identity; religion; Republic of Moldova.

\section{INTRODUCTION AND METHODOLOGY}

Our analysis aims to consider the establishment of a link between the identification of borders (possibly understood as identity cleavages) and the identity realities present in the space of the Republic of Moldova.

Beyond the many facets that identity acquires, the perspective of identity cleavage in the central and eastern space of Europe often seems to be as real as possible and demonstrated by more or less recent historical realities. The identity, be it that of an individual, a group or a community, can generate convergence, but also divergence in relation to the other. The other, dichotomous, acquires the expression of the "beyond"; beyond what is specific to one, to one's identity. A frontier, be it symbolic or ideological, can thus be identified around identity constructions. Central and Eastern Europe does not only make no exception to this rule, but, in our assertion, it is the space that imposes, perhaps most in Europe, such identity borders.

Methodologically, the focus of our analysis lies primarily on the identity boundaries generated by the specific ethno-religious, linguistic or cultural, but also by the nature of the mental specific to the area. This paper develops in a new methodological construction ideas and synthetic research contained in a previous paper on identity as a border in the space of Central and Eastern 
Europe (Brie 2016, 359-381).

Without aiming at analysing the entire identity spectrum in the Republic of Moldova, throughout this study we want to identify possible identity cleavages that take the form of identity borders. The identification is accompanied by a process of conceptual analysis with comparative references to other European geographical areas.

Our hypothesis is built starting from the assertion that in the space of this state there are realities that converge towards the daily expression of some community-identity borders. These boundaries can be identified both in terms of ethno-national and linguistic identity and in terms of religious identity. In these situations, the political or geopolitical connotations and implications are very important and acquire the valences of some decisive factors in the identity development.

Methodologically, we specify that throughout this study we do not intend to solve in any way fundamental, existential problems or to clarify possible identity dilemmas or older or newer controversies.

Our objectives are to analyse possible identity realities that can generate, at the societal level, certain cleavages that take the form of identity boundaries. Therefore, our debate is oriented towards the identification of these borders, to discuss them in terms of the possible cleavage they produce. It is necessary to specify that, in our assertion, the existence of an identity border does not necessarily imply a rupture, a discontinuity, but can also be interpreted as a cultural-identity contact area. Such a contact area can generate not only multiculturalism, but also the development of an intercultural society in which cleavages fade.

Throughout this extensive analysis, we propose a general debate on identity issues, often of great sensitivity in the space of the Republic of Moldova. In this sense, the approaches of conceptual analysis are accompanied by comparative references similar or different realities as an expression and result from other European countries. 


\section{THE EUROPEAN AND NATIONAL CONTEXT}

Since the nineteenth century, the European space has undergone an extensive process of identity transformation. The European societies are modernizing, and under the impact of modernization there are profound changes both at the domestic level and at the international level.

The identity revolution was not only specific to the period of the second half of the nineteenth century, when the effervescence of the new led to the erosion of the old monarchical order of powerful governments. The peoples are developing an increasingly strong national consciousness, culminating in the principle of self-determination of the peoples, so much the scene of the treaties that regulated order after the First World War. Then one of the most visible transformations has in view the national and identity emancipation.

Today, the process continues and develops on new levels of identity. At the same time, more and more "border" cleavages are emerging within European societies. These boundaries are most often symbolic and ideological.

In the contemporary period we are witnessing an effervescence of the national, despite the progress made at European level in terms of consolidating the European identity. The process of European construction was accompanied by a certain blurring of the national, at least at the level of expression of nationalistextremist movements. European identity appears as a higher-ranking identity that reduces the forms of expression of national and regional identities. This at least in theory. On the other hand, in the current context, we are entitled to believe that European identity has taken a form of manifestation in parallel with national or regional levels, without being in very close relationship with them. That is, the reduction or amplification of the forms of manifestation at one level does not lead to a counterweight at another level (Brie 2018, 237).

Diachronically, stimulated by the phenomenon of globalization, by the success of the EU, especially by the European enlargement to the east and the disappearance of the "Iron Curtain", the European identity experienced an exaltation both at the level of public discourse and at daily level. The phenomenon has, in our opinion, another facet: the identity revenge of the current period. As a result of crises that have become systemic at EU level 
(economic, financial, social, institutional or legitimacy), of new geopolitical realities in the neighborhood area (e.g. the situation in Ukraine, the Middle East, North Africa), but also as an effect of mass migration, we find a return to local, regional or national identities (To be seen for more details Brie and Blaga 2015, 255-273).

Without proposing on this occasion to make an analysis of the political realities, respectively of the discourse of the political leaders, in the European space, but not only, we are witnessing in this period, more than in other stages of the history of the last hundred years, a radicalization of the discourse with an emphasis on the national. Political movements are gaining more and more national, ethno-cultural and identity nuances. Not only populism is gaining ground, but also the xenophobic, tribal debate of fear and danger portrayed in the image of the other (Brie 2018, 238).

The European Union, Russia, globalization, immigrants, multinationals, national minorities, but also others who are not part of the besieged national community, are real scapegoats that political leaders in Central and Eastern European countries, for example, use to generate emotion and capitalize on the increasingly nationalist expressions present in these countries.

The countries of the Visegrád group, once exemplary for the pro-European orientation, began to develop Eurosceptic attitudes strongly accompanied by nationalist discourses within less than ten years after their accession to the European Union. The national revenge seems to be favoured by the impossibility of Brussels to bring its captive citizens closer at national level. The failure of some turns into the success of others who come as rescuers to defend the besieged nation. In Poland, nationalism, more precisely the romantic nationalism, has gained ground since October 2015, when Jaroslaw Kaczynski's Law and Justice Party (PiS) got to power. Viktor Orbán, the first Hungarian minister, has consolidated his position at the internal political level by promoting strident nationalist discourses and arrogant with relation to everything foreign, irritating even the closest allies. His party, Fidesz has thus led Hungary towards a nationalist and populist iliberalism (Manolescu 2017).

Nationalism is on the rise in the European states. It takes on various forms, such as the pro-independence movements from Catalonia and Scotland, or, more 
frequently, of populist and right-wing reactionary doctrines. Far-right or national-conservative populist formations are represented in the executives of several European Union member states.

This picture is complemented by the nationalist rhetoric of political leaders such as Vladimir Putin in Russia or Recep Tayyip Erdoğan in Turkey. In both cases, the rhetoric often refers to the glorious imperialist past of its own histories that it would like to revive, even if only in the minds of its own citizens that it mobilizes in support of such projects in relation to internal and external enemies (Brie 2018, 238).

Beyond all this, many European countries must find solutions to the growing demands of national minorities.

In the current context of the crisis, cooperation and dialogue often have room for suspicion and competition. States are repositioning themselves on national criteria in relation to the economic problems they have. Many political leaders have built their public discourse through the fault of other European partners and hence the radicalization observed in the public space. The Austrian Leopold Kohr's Theory of Small States ${ }^{1}$ comes back to actuality. Thought on an economic basis, this theory gains more and more supporters from the perspective of the states' political and national funcționality. 'The solution to global problems is not more unity and growth, but more division; the world must be fragmented into several small states, the economies of which will be much more flexible" (Furtună 2015). Starting from this theory, numerous geopolitical maps have emerged that try to substantiate the idea of the functionality of smaller states in the European space.

In the following part we present only three of these map-projects. One of them proposes the fragmentation of European countries into 73 autonomous or independent ethno-cultural regions, which should reflect about as many ethnocultural or linguistic entities (there are serious reservations but in terms of identity in the case of many of these regions) (Furtună 2015).

1 În 1957, Kohr publishes the work The Fall of Nations in which he argues that small states, small nations and small economies are more peaceful, prosperous, and more creative than big states and great superpowers. 


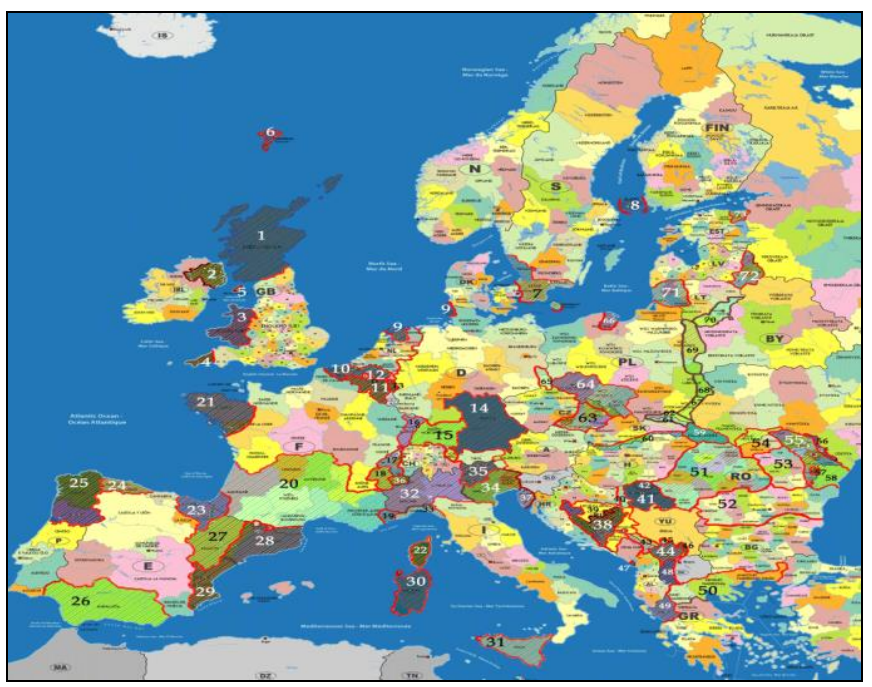

Figure 1. Project a "Europe of regions"1

Source: Furtună, 2015

At the level of the current period, in Europe there are numerous ethno-national claims that imply autonomous or even territorial separation demands through independence. If all these movements were successful, then the map of Europe according to Mauldin Economics- would look like this:

1The map was drawn on the basis of the materials of the Round Table of the League of Conservative Journalism with the title "United Regions of Europe: Kosovo as a Forerunner in the European Globalization Process". 


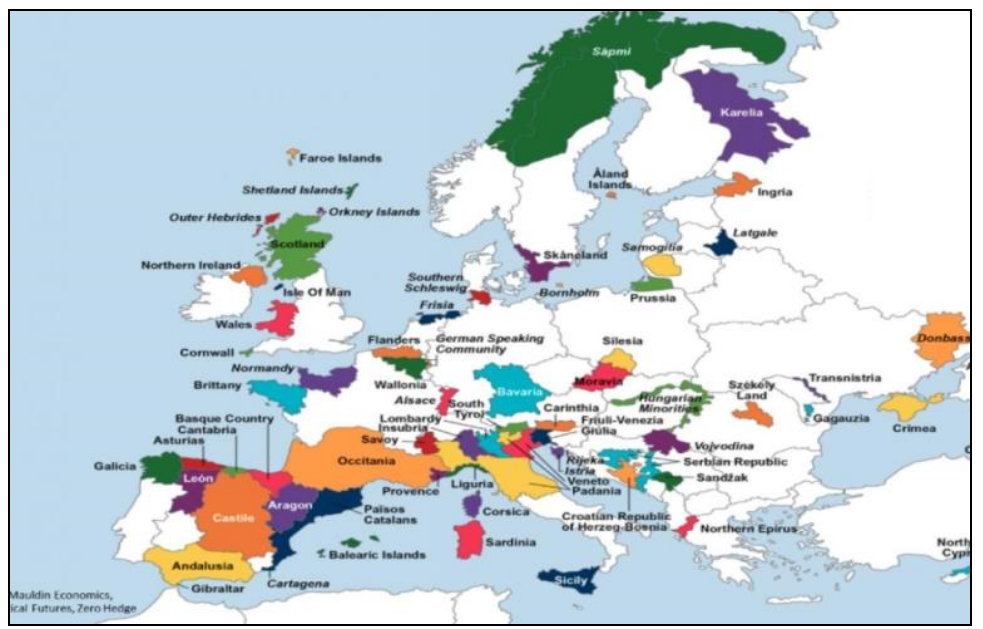

Figure 2. Europe of the secessionist movements Source: Mauldin Economics 2017.

At a conceptual level, identity constructions appear, apparently placed on the same level of analysis, they can have different connotations. Identity, regardless of the level of reporting (European, national or regional / local), is found as a form of expression in the public space despite universal trends, globalization or uniformity of values, characteristics or community expressions. The elements of ethno-religious identity are found in the global public space, inclusively in forms multiplied through the channels of global propagation. Therefore, not only the global multiplies itself, but also the particular, the specific.

The latter, often taking forms of extremism, nationalism, ethno-religious violence, are multiplied by gaining followers thousands of miles away. Then, the national and ethnic state, associated with the national territory, managed not only to survive the pressures of the "global society", but also demonstrated an even greater capacity for affiliation.

The Identity globalization has proven to be stronger in urban and industrialized societies, and where there are consistent rural areas, a rich heritage and cultural tradition, a resistance to globalization has developed (Poenaru 2012). Thus, the 
local, national-cultural identity is more strongly preserved in the ruralagricultural environment and in the area of reference proximity of cultural sites. Such a reality does not exclude the possibility of the parallel development and consolidation of a European supranational identity. Conceptually, this seemingly antagonistic relationship appears: European identity versus national / local identity (Brie 2016, 360).

We hereby propose three levels of analysis regarding the concept of identity: the European level, the national level and the regional level. A European can be Italian, German or Romanian. At the same time an Italian can be Sicilian, Neapolitan, Venetian, Piedmontese, Tuscan, etc; a German can be Bavarian, Saxon, Prussian or even Austrian. At the same time, Transylvanians, Oltenians, Banatians or Moldovans can express together the feeling of Romanian Romanianness.

The specialty literature captures the dispute over the establishment of the identity of a person or community. The process comprises two dimensions: selfidentification and hetero-identification. In both situations, both one's own identification and the identification made by someone else, the debate on identity involves both objective and subjective elements.

Theoretical analyses, on the other hand, seize a dispute around the subjective and objective dimension of identity. Unlike the concept of national origin, which refers to something given, inherited by birth, national identity is, above all, the expression of the consciousness of belonging to a cultural community that is defined as a political community.

Ernest Renan refers to this reality when he characterizes the nation, suggestively, as a "daily plebiscite" (according to Flóra 2011, 114). The national identity in this case is related to the concept of nation. The latter one understood as a population that divides a territory (to which it relates through the historical dimension), myths and common historical memories, a mass culture, a common economy and common legal rights and duties for each member (the latter referring to the state political organization) (Brie and Blaga 2015).

This analysis presupposes the existence of: 1 . a segment of the population living in a certain territory; 2. a certain type of relationship that expresses the consciousness of identity and belonging, a "community spirit" (Brie and Blaga 
2015, 115).

Such a perspective on the nation is in line with the philosophy of the Westphalian state that focuses on the idea of state-nation-territory.

Conceptually, the entire identity building has at least two elements of specificity ever since its construction (Brie 2016, 362-363):

- national identity born of ethnic belonging

- national identity born of civic / citizen affiliation

In the first case, national identity serves a certain ethnic group that is often in competition with other ethnic groups (most often present in the same reference space).

The perspective gives rise to nationalist-tribal expressions that may involve the exclusion of representatives of other ethnic groups.

In the second situation, the civic dimension serves the state, leading most often to patriotism (the perspective is rather positive compared to the first situation when we are dealing with a perspective with negative connotations!)

The analysis of the two dimensions has led some analysts to identify the main differences in the conceptual debate on identity in Central and Eastern Europe versus the United States. The essential difference is that the European national identity gives an answer the question of who is Romanian, Hungarian, Slovak, etc. (i.e. what makes us different from each other), whereas the American one seeks to identify those elements that citizens have in common (what makes the different citizens in many situations in terms of ethno-culture to be Americans?) (Bujalos 2011, 79-91). This conceptual dispute between European and American national identity / nation can be extrapolated at the level of the European space as well. The idea of nationality is perceived differently in Western and Central Eastern Europe.

In most Western countries, the national identity has been built mainly around the identity of a citizen, and the territory of the status has consequently become the fundamental term of reference for the "national territory" - the civic dimension of national identity.

Eastern Europe has had a different pattern of development, in which ethnicity, the ethnic belonging or affiliation has fulfilled a fundamental role in building the national identity - the ethnic dimension of national identity (Flóra 2011, 116). Thus, 
the Western model of the nation emphasizes the central position of the national territory or homeland of the nation, while the Eastern model is concerned with ethnic origin and cultural ties.

A fundamental feature of state-type nation-state constructions in Eastern Europe is their permanent lack of legitimacy or, rather, their incomplete legitimacy.

By identifying the state with a single national identity, the other national communities inevitably found themselves outside this process of legitimation, which constituted a fundamental source of inter-ethnic tension.

This reality has led to the sacralization of the state territory considered national territory (Flóra 2011, 118-128) (the righteous property of a single nation/nationality!), while the cultural-historical philosophy is to delegitimize as much as possible the contribution of other national communities (Brie and Blaga 2015).

With regard to the European level of analysis on the concept of identity, the legitimate question is to what extent we are talking about a common European identity or, in antithesis, about the presence of identity borders in the European space. A certain identity cleavage can be observed between Western and Eastern Europe. This reality is given by the historical, cultural, religious and political heritage.

\section{ANALYSIS OF THE RELATIONSHIP BETWEEN IDENTITY AND BORDER}

As it is easy to understand, such an analysis gives rise to emotions and can stir up certain latent manifestations in the public space. From the beginning, we make it clear that we do not aim to find truths or answers, but only to identify and analyse possible identity boundaries.

We do not want to position ourselves on one side or the other of the debates (the existence of identity borders presupposes the presence of at least two identity constructions that meet, often located on divergent positions!).

Each of the general themes identified as generators of identity borders have constituted and can constitute in themselves fundamental theses that require 
complex analyses both qualitatively and quantitatively. In this case, we propose to the academic environment topics for reflection and analytical perspectives upon topics of particular sensitivity in our European societies.

With the aim of a conceptual clarification and in order to respond to the methodological desideratum already announced, we hereby make some comparative references to the case of the states of Northern Macedonia, BosniaHerzegovina and Montenegro or to the case of the Albanians in the Balkans.

The fall of communism and the Soviet and Yugoslav disintegration have initially amplified, in a first stage, the process of identity emancipation and the emergence of new cleavages in the Balkan and ex-Soviet space.

\subsection{Moldovanism as an ethno-national identity border}

A strong identity supports and justifies a strong statehood. Logic has often been used by political regimes and vice versa, in order to justify national-state constructions newly appeared on the European map.

Thus, the existence and survival of a political-state construction came to depend, among other things, on the need for an identity construction that would give an individuality in relation to neighboring states and peoples, drawing not only state borders but also identity borders.

The Republic of Moldova, like the state of Montenegro, developed in the first decade after independence a specific policy aimed at highlighting the unitary relationship of the triangle state, nation, citizenship (to be seen Chapter 2 additionally: Transitional Triangle: State, Nation, Citizenship, Džankić 2015). The three dimensions must be mutually supportive and mutually reinforcing. If the national dimension is weaker, statehood and citizenship must sustain and justify national existence and consolidation.

In Montenegro, statehood and citizenship support the nation in the absence of very clear distinctive landmarks that separate the ethno-religious and linguistic identity of the population of this state from the Serbian nation.

From this perspective the identity construction is an ongoing, developing process. This process highlights not only a new ethno-national identity reality, 
but also an increasingly pronounced linguistic and cultural one (the latter by appealing to the historical heritage that would justify the current identity boundaries).

A controversy arises, as in the case of Northern Macedonia, over the very name of the state East of the Prut. The Principality of Moldova, through the treaty of Bucharest between the Ottomans and the Tsars, lost the eastern part of the Prut. After this date, the state continued to exist only in its part west of the mentioned river, and then, by the union with Wallachia (1859), this statehood was transferred within the Romanian state.

The territory between the Prut and the Dniester, called Bessarabia (it is true, more by the Romanians in Romania) experienced in the period following the Russian annexation several stages: 1 . the period up to 1918, respectively belonging to the Tsarist Empire; 2. the period 1918-1940, when Bessarabia was part of Greater Romania; 3. the period 1940-1991, respectively the Soviet period; 4.the period after the proclamation of the state independence of the Republic of Moldova.

The symbolism of the statehood of the Republic of Moldova, despite much more recent rhetoric, goes back ancestrally to a glorious Middle Ages of the first Moldavian rulers (claimed to be Romanians by the Principality of Moldova which was not occupied by the Russians in 1812).

Moldovanism, as an identity construct, gave rise to many debates and controversies regardless of where it was viewed and analysed. However, it was always used for political or geopolitical purposes.

The controversy is not clarified at home either, without extending the debate to other geographical areas the geopolitical interests of which do not converge towards the same objectives. The debate between Moldavianism versus Romanianism often ignited the spirits east of the Prut, fed more or less from the West and East.

The two perspectives seem to be entirely opposed. The Romanian perspective includes Moldovans, along with Transylvanians, Oltenians, Muntenians, among Romanians (being Moldovan is not an ethno-national-linguistic identity, but a regional-geographical one, and represents a sub-national dimension!).

The perspective of Moldovanism excludes from the beginning the common 
identity, of nation and language or an overlapping identity such as Bavarian are the Germans, and the Germans are Europeans (being Moldovan means actually not being Romanian and vice versa!).

Regardless of the fact that Moldovanism was disproportionately created and fueled by tsarists or Soviets, it massively served the political interests of the rulers of Chisinau after the proclamation of independence.

Initially, an attempt was made to create a nation-state in which the Romanian language was recognized as an official language, and the doctrine of "one people, two states" was officially accepted by both sides of the river Prut. National minorities, intensely supported from the outside, found it difficult to reconcile with this reality and reacted.

The "imaginary dangers" of the union of the young Moldovan state with Romania and of discrimination according to ethnic or linguistic criteria have generated the beginning of a double secessionist process, in the East and in the South of the republic, a process that culminated in the outbreak of an armed conflict on the left bank of the Dniester" (Cărbune 2010).

Moldovan President Mircea Snegur officially renounced this doctrine on July 29th, 1994, with the adoption of the new Constitution (Constitution 1994). The thesis regarding the Moldovan identity, different from the Romanian one, is resumed and amplified.

Used by tsarists and Soviets to justify separation from the Romanian state, it now serves political interests that speak of the national interest, namely the preservation of Moldovan statehood that would be threatened.

In theory, Moldovanism as an identity construct is used in the sense of developing a national identity related to civic, citizenship affiliation. The new identity aims at bringing together all the citizens of the Republic of Moldova regardless of their ethno-national or linguistic options.

Even if the new authorities that took power in Chisinau from the communists after 2008 changed the logic of identity argumentation, Moldovanism remains a source of controversy.

While some Moldovan citizens proclaim their Romanian ethno-national and linguistic identity, others, along with the minorities present in this space, support Moldovanism as a distinct identity from the Romanian one, which they 
see as a danger of undermining the statehood of the Republic of Moldova.

Thus, in the Republic of Moldova we are talking about Romanian Moldovans and Moldovan Moldovans.

The process is similar up to a point in Montenegro, where there are many who claim that the language spoken is but the Serbian language, and that they are nothing more than Serbs belonging to the Montenegrin nation built on the basis of citizenship and affiliation to a distinct statal space.

\subsection{Linguistic individuality: foundation of Moldovanism}

The linguistic individuality of a people has always played an important role in consolidating statehood. A distinct language leads to an additional force to preserve statehood.

People who speak the same language, distinct from other communities it comes in contact with, develop forms of community solidarity of identity origin. The biblical episode, also related in the Qur'an, of the construction of the Tower of Babel is very well known.

"Let us build us a city and a tower, the top of which may reach to heaven, and let us make a name for ourselves, that we may not be scattered over all the face of the earth!" (The Bible, Genesis, chpt. 11: 4). "Behold, they are one people, and they all have the same language, and this is why they have begun; now nothing would stop them from doing everything they had in mind." (The Bible, Genesis, chpt. 11: 6) "Let's descend upon them and confuse their language there, so that they don't understand each other's words! And the Lord scattered them abroad from thence upon the face of all the earth: and they left off and build the city." (The Bible, Genesis, chpt. 11: 7-8)

The biblical episode identifies from ancient times the strength of a linguistic community, of a people who speak the same language. They can work together, they can build something great, they can fight together, they can stay together just because, and only and only if they speak the same language.

The others are not trustworthy, they cannot be from within, one has to separate oneself from them and find one's support only next to those who speak the same 
language with you.

This foundation is not only the basis for the establishment of modern nations, but also both justifies and is an argument for the complicated policies that underlie identity revolutions, but also regimes or political movements that support separatist movements or the justice of new state constructions.

Among the concerns regarding the consolidation of the statehood of the new Balkan and ex-Soviet states there was the promotion of the linguistic individuality of the new peoples.

Moreover, the movements of national emancipation or identity-national construction, started long before the act of independence, were based on and justified on ethno-national, religious, cultural and linguistic individuality.

The case of the Republic of Moldova is not singular. In Montenegro the situation is somewhat similar. The public policies and public discourse have led to the assertion of linguistic individuality in relation to the Serbian language.

If the Serbian language was initially accepted as the official language, the 2007 constitution requires the "Montenegro language" as the official language, which has caused dismay on the Serbian side (Morrison 2018, 138).

In the Republic of Moldova, this controversy is related to the promotion of Moldovanism as an identity. The Moldovan language, as a language distinct from the Romanian language, serves the same interests and political or geopolitical objectives.

Regardless of the origin of this dispute, the society in the Republic of Moldova is linguistically divided not only in relation to national minorities, but also in relation to the language options of the ethno-national group that forms a majority.

The process of Russification in the Tsarist and Soviet periods served to implement the doctrine of the two different languages: "Romanian" and "Moldovan".

Multinational imperial states, they in turn accused the Romanian "imperialism" upon another people: the Moldovan one, speaking another language: Moldovan language.

The Declaration of Independence of the Republic of Moldova (1991) (to be seen the text of the Law 1991) makes clear reference to the "deciding by decree the 
Romanian language as a state language", a language that Moldovans used and considered identical to their own.

The promotion of Moldovanism became again the official politics of the Chisinau authorities after 1994, deepening confusion and controversy. The official language of the Republic of Moldova is, according to the new constitution, the "Moldovan language" with Latin spelling (Constitution 1994, art. 13).

The contradiction continued despite the attempts made by the new persons governing (after 2008) to restore the Romanian language to its rights as official language of the state. It was as late as December 5-th, 2013, that the Constitutional Court of the Republic of Moldova solved this dilemma and the interminable dispute concerning the official language of the state.

The judges, considering the text of the Declaration of Independence and the text of the Constitution decided that the text of the first document prevails over the Constitution, and "the state language of the Republic of Moldova is Romanian". "The Declaration of Independence constitutes the legal and political basis of the Constitution, so that no provision of the latter can go beyond the scope of the Declaration of Independence. Thus, the Court concluded that, in case of a divergence existent between the text of the Declaration of Independence and the text of the Constitution, the primary constitutional text of the Declaration of Independence prevails. The decision shall be final and shall not be subject to any appeal" according to the president of the Constitutional Court, Alexandru Tănase (The Constitutional Court via realitatea.md 2014). Apart from the intervention of the Constitutional Court, the controversy and disputes with regard to identity of the Moldovan language are meant to perpetuate this symbolic frontier, often used with ideological purposes.

\subsection{The Cyrillic alphabet as an identity border}

The alphabet is also used as a distinct identity element that can take the form of a cleavage such as identity boundaries. If in the case of the Albanians in the former Yugoslavia the use of the Latin alphabet was accompanied by the existence of a clearly distinct language, in the case of other peoples who were 
part of the former federal state the linguistic individuality was not so clear. For a long time, the linguistic individuality of Croats in relation to Serbs was linked to the use of the Latin alphabet by the former and the use of the Cyrillic one by the Serbians.

This dispute can be identified as I mentioned earlier in the case of Montenegro (Morrison 2018, 130-152) or the existence of a separate Bosnian language (Džankić 2015, 48). The alphabet has played every time a very important role in the justice of the decision to draw a linguistic boundary of an identity nature.

In the case of the Republic of Moldova, the introduction of the Cyrillic alphabet as a distinctive element in relation to the Romanian language was a weapon used by the Soviet regime but also the Russian one (both the Tsarist and current one). In Transnistria, Cyrillic spelling is still used to write "Moldovan". The choice of the alphabet has often proved to be a political act aimed at often solving geopolitical problems (to be seen the case of the Soviet Republics presented by Alexe and Ciapai 2021).

The issue of the Cyrillic alphabet in the identity dispute of Bosnian Serbs has come back on the agenda. In this case, in addition to religion, the Cyrillic alphabet plays a very important role as a border of identity.

September 15th, on the occasion of Serbian 'Unity Day', MPs from the two parliaments of Serbia and Republika Srpska passed two laws to encourage the use of the Cyrillic alphabet in a new attempt to strengthen a common national identity (Traci 2021). All public institutions and societies, schools and universities, national associations and companies are constrained to use the Cyrillic alphabet (Cyrillic alphabet 2021). Moreover, private companies are promised tax reductions provided they use this alphabet. The Cyrillic alphabet is part of an increasingly complex means that puts nationalism back in the complicated Balkan republic of Bosnia and Herzegovina.

Recently, the Bosnian Serb leader Milorad Dodik, co-president of the state of Bosnia and Herzegovina, rekindled nationalism, sowing the seeds for the resumption of the conflict, with new demands for the separation of Republika Srpska (a region with 1.2 million inhabitants). The other two co-chairs, Sefik Djaferovic (representative of the Bosnian community) and Jeliko Komsic (representative of the Croatian community), issued a joint statement expressing 
their support for the preservation of the current borders and their readiness to fight for it (Andrei 2021).

\subsection{Religion as a border: its role in the national construction}

In the Balkans, religion has always been an element of community individuality in relation to which the boundaries of identity-national communities, and even of states, have been drawn.

In the former Yugoslav state, despite numerous efforts made after the Paris Treaties to achieve national cohesion, religion has always been an impediment to this success. Slovenes and Croats are mostly Catholic Christians, Serbs, Montenegrins and Macedonians are mostly Orthodox Christians, Albanians and Bosnians are Muslims.

This mosaic picture is very visible, through the role played by religion in drawing identity borders, in Bosnia and Herzegovina. The Serbs are Orthodox, Croats are Catholics, and Bosnians are Muslims. Despite efforts to standardize language, religion (but not only it!) it has kept the ethno-national communities distinct.

Moreover, neither is there any longer the same unity within Orthodoxy itself, if we consider the case of the Church in Montenegro. Here an important part of the population reproaches the hierarchical superiority of the Serbian Church and challenges it.

Somewhat similar to the situation in Montenegro is the religious reality in the Republic of Moldova. Here, the Law on Freedom of Conscience, Thought and Religion (Law 2007) preserves the provision in the old law of cults in the Republic of Moldova that obliges the state to register as a religious cult any organization that had at least 100 members.

This reality has led to the emergence of parallel Orthodox religious organizations that each claim their authenticity and legitimacy. We do not intend in the present study to discuss those "autocephalous" communities that represent a small number of parishioners (Orthodox community via moldovacrestina.md 2021), but to consider first of all the largest of them: 
- The Metropolitan Church of Chisinau and all of Moldova (also called "Moldovan Orthodox Church"), affiliated to the Moscow Patriarchate

- The Metropolitan Church of Bessarabia and the Exarchate of Plai, autonomous church, part of the Romanian Patriarchate

The first of these, having the most parishioners, registered in Moldova in 1993, claims to be the successor of the Diocese of Chisinau established in 1812 by the Russian Church (Diocese of Chisinau 2021).

The second one declares itself the successor of the Metropolitan Church of Bessarabia, which existed between the years 1918/1924-1940 and 1941-1943, but also the heir of the Romanian Orthodoxy, which existed on the territory of Bessarabia from the beginning until 1812 (for more details on its history we recommend the documentary material prepared by Gomboş 2016).

The two churches often challenged each other, maintaining strained relations that they conveyed to the parishioners. Moreover, this organization also reflected the geopolitical trends from Moscow and Bucharest. In the Republic of Moldova, the two churches bore banners of a struggle that the two patriarchates could not afford to display.

\subsection{The identity controversy of the Gagauzians in the Republic of Moldova}

The Gagauz community has always been a border community. This reality is due precisely to the often controversial positioning between the Bulgarian, Turkish and more recently Russian identity of the members of this community. Beyond their controversial origin, their identity involves significant nuances throughout historical stages that marked their existence. This community has transformed itself increasingly into an identity towards what is today a Russophile community, systematically supported by Moscow.

Without being very numerous (according to the 2004 census, it amounted to 147,500 members, of whom 127,835 lived in the Gagauzia Autonomous Territorial Unit) (National Bureau of Statistics 2004), this community stands out for its importance in the history of Bessarabia.

The most accepted theory about their origin is that they are descendants of 
Turkish tribes, possibly Oghuz or even Seljuks. Other historians speak of Cumanian, Pecheneg, or Bulgarian origin. ${ }^{1}$ Certainties, however, are the Turkish origin of their languages and the fact that they became Christians, renouncing Islam under the influence of Byzantium (Pârlog 2012).

Their presence in Bessarabia is linked to a migration from Bulgaria to Dobrogea and Bessarabia in the late eighteenth century. The annexation of Bessarabia by the Tsarists turned them into their dispute, often with the Turks, but also for control of the new province, into Orthodox Christian allies increasingly willing to accept the cultural-political rapprochement.

Instead, the Russians granted them privileges, tax exemptions, exemption from military service, a.o. (Pârlog 2012). The Soviet period brought them even closer as identity with the Russians, so that now the Russian language could be assumed collectively.

After gaining the state independence by the Republic of Moldova, together with other minorities, they militated for the creation of an autonomous region, that of Gagauzia, culturally supported by Ankara, which opened a Turkish Cultural Center and a Turkish Library here (Brie 2016, 374-375). All this turn this community into a border identity, into one of a cultural-identity contact.

\section{CONCLUSIONS}

At a comparative level, the reality of identity cleavages, which most often takes the form of borders, is similar in the Republic of Moldova and in the Balkans. However, a particular note is kept given by the context, the specificity and the geopolitics of the former Soviet space in relation to the former Yugoslav one.

Identity dilemmas and controversies in the Republic of Moldova, as well as

1 Bulgarian historians consider them simple Turkicized Bulgarians who have preserved their Christian-Orthodox religious identity, https://romaniabreakingnews.ro/cine-suntde-fapt-gagauzi-cei-folositi-azi-de-rusia-pe-post-de-unealta-geostrategica-si-amenintarepermanenta-la-adresa-suveranitati-integritatii-teritoriale-a-r-moldova/, accessed on November 16-th, 2021. 
others in Central and Eastern Europe, are determined/fueled by the geopolitical interests of some states / powers that have used them to expand or maintain influences. Here the boundaries of identity took the form of ideological or symbolic boundaries.

The society in the Republic of Moldova seems to be fragmented. Perhaps one of the most present dilemmas is the choice of national identity. Intentionally avoided this time, in the Republic of Moldova there is a public debate that seems inexhaustible about the option of being Moldovan or Romanian in an ethnonational sense.

\section{REFERENCES}

- Alexe, Dan, and Alla Ciapai. 2021. Cyrillic, Latin or Arab? The system of description is often a political act. Accessed October 28, 2021. https://moldova.europalibera.org/a/chirilice-latine-sau-arabe-sistemulde-scriere-e-deseori-un-act-politic/31431391.html.

- Andrei, Veronica. 2021. Liderul sârbo-bosniac Milorad Dodik se joacă cu focul în Balcani. Amenințări la adresa NATO, [Bosnian-Serb leader Milorad Dodik is playing with fire in the Balkans. Threats to NATO]. Accessed October 29, 2021. https://m.ziare.com/international/bosnia-hertegovina-milorad-dodikbalcani-republica-srpska-1707411.

- Brie, Mircea, Daniela Blaga. 2015. "Identity rematch in the European space". Alina Stoica, Ioan Horga, Mircea Brie. Cultural Diplomacy at the Eastern and Western Borders of the European Union. 255-273. Oradea: University of Oradea Publishing House.

- Brie, Mircea, Daniela Blaga. 2017. "Image of the Other: the Perspective on Ethnicity". Dana Pantea, Ioan Horga, Mircea Brie. The Image of the Other in the European Intercultural Dialogue. 91-109. Saarbrücken: Lambert Academic Publishing.

- Brie, Mircea, Ioan Horga. 2010. "Europa: frontiere culturale interne sau areal cultural unitar". Moldoscopie nr. 3 (L): 123-143. Chișinău.

- Brie, Mircea, Ioan Horga. 2014. "Le frontiere europee - espressioni dell'identità". Transylvanian Review". vol. XXIII. suppliment nr.1: 202-216.

- Brie, Mircea. 2014. "European enlargement and new frontiers Central and 
Eastern Europe". Studia Universitatis Babeș-Bolyai. Series Europaea. LIX, 1: 113-130. Cluj-Napoca,

- Brie, Mircea. 2016. "Identity as Frontier in Central and Eastern Europe. The Case of the Republic of Moldova". Mircea Brie, Alina Stoica, Florentina Chirodea (coord.). The European Space Borders and Issues. In Honorem Professor Ioan Horga. 359-381. Oradea/Debrecen: University of Oradea Publishing House/Debrecen University Press.

- Brie, Mircea. 2018. "Identity Revolution and Minority Emancipation: A Cause of the European Concert's Crash. Contemporary Analogues". Ioan Horga, Alina Stoica (coordinators). Europe a Century after the End of the First World War (1918-2018). 245-248. Bucharest: The Academy of Romania Publishing House.

- Bujalos, István. 2011. "Identitatea personală şi națională în filosofia americană [Personal and national identity in American philosophy]". Balogh Brigitta, Bernáth Krisztina, Bujalos István, Adrian Hatos, Murányi István (coord.). Identitate europeană, națională şi regionala.Teorie şi practică [European identity, national and regional. Theory and practice]. 79-91. Oradea: Partium Publishing House.

- Cărbune, Radj. 2010. Identitatea națională a Republicii Moldova [National identity of the Republic of Moldova]. Accessed October 08, 2021. https:/ / radjcarbune.wordpress.com/2010/12/02/identitatea-nationala-arepublicii-moldova/.

- Constitution. 1994. Constitution of the Republic of Moldova din 29.07.1994. $\begin{array}{lll}\text { Accessed } & \text { October } & 15,\end{array}$ http://www.wipo.int/edocs/lexdocs/laws/mo/md/md046mo.pdf.

- Costea (Ghimiș), Ana Maria. 2015. National Preferences of the EU and NATO Member States at the Eastern Border. Study Case: Romania and Poland. doctoral thesis. Babeș-Bolyai University Cluj-Napoca.

- The Constitutional Court via realitatea.md. 2014. "Curtea constituțională: Limba de stat a Republicii Moldova este limba română" (The Constitutional Court: The state language of ther Republic of Moldova is the Romanian language). Timpul.md. 5 December 2014. Accessed November 11, 2021. http:/ / www.timpul.md/articol/curtea-constituionala-limba-de-stat-arepublicii-moldova-este-limba-romana-67053.html.

- Cyrillic Alphabet mandatory. 2021. The law to be adopted: Cyrillic Alphabet mandatory. Accessed October 15, 2021, https:/ / www.b92.net/eng/news/ society.php?yyyy=2021andmm=08andd 
d=27andnav_ id=111549.

- Diocese of Chisinau 2021, official site. Accessed October 08, 2021. http://mitropolia.md/.

- Džankić, Jelena. 2015. Citizenship in Bosnia and Herzegovina, Macedonia and Montenegro: effects of statehood and identity challenges. Routledge.

- Flóra, Gábor. 2011. "Identitate şi ideologie națională: o perspectivă socioistorică [National identity and ideology: a socio-historical perspective]". Balogh Brigitta, Bernáth Krisztina, Bujalos István, Adrian Hatos, Murányi István (coord.). Identitate europeană, națională şi regional. Teorie şi practică (European identity, national and regional. Theory and practice). Oradea: Partium Publishing.

- Furtună, Dorian. 2015. Teoria statelor mici şi „socul identitătilor" (The theory of small states and the "shock of identities). Accessed October 29, 2021. http:/ / adevarul.ro/international/europa/teoria-statelor-mici-soculidentitatilor-1_54cbaa85448e03c0fd1d9624/index.html.

- Gomboş, Stelian. 2016. Romanian Orthodox Metropolitan Church of Bessarabia. Accessed October 9, 2021. http://www.crestinortodox.ro/religie/mitropolia-ortodoxa-romanabasarabiei-122930.html.

- Huntington, S. 1997. "The Erosion of American National Interests". Foreign Affairs. Council on Foreign Relations. vol.76. no.5. 28-49.

- Law. 1991. Law No. 691 of n27.08.1991 on the Declaration of independence of the Republic of Moldova. Accessed October 14, 2021. http:/ /istoria.md/articol/573/Declara \%C5\% A3ia_de_Independen\%C5\%A 3\%C4\%83_a_Republicii_Moldova.

- Law. 2007. Law No. 125 of 11.05.2007. Legea privind libertatea de conştiință, gândire şi de religie (The Law on Freedom of Conscience, Thought and Religion) published on 17.08.2007 in The Official Gazette No. 27-130. art. 546. Accessed October 21, 2021. http:/ /lex.justice.md/viewdoc.php?action=viewandview $=$ docandid $=32488$ 9andlang=1.

- Manolescu, Andrei. 2017. Ungaria lui Orbán (Orban's Hungary). Accessed October 29, 2021. http://dilemaveche.ro/sectiune/tilcshow/articol/ungaria-lui-orban.

- Mauldin Economics. 2017. Geopolitical Futures Zero Hedge via Bank of America Marrill Lynch. according to Business Insider. Accessed October 2, 2021. http://uk.businessinsider.com/map-of-european-independence- 
movements-2017-6.

- Morgenthau, Hans. 2007. Politica între națiuni. Lupta pentru putere și lupta pentru pace. Iași. Polirom.

- Morrison, Kenneth. 2018. Nationalism, Identity and Statehood in Post-Yugoslav Montenegro. Bloomsbury Publishing Plc.

- National Bureau of Statistics 2014. National Bureau of Statistics of the Republic of Moldova. Population Census 2004. accessed on November 16-th, 2021.

http://www.statistica.md/ pageview.php?l=roandidc=295andid=2234.

- Orthodox community via moldovacrestina.info. 2021. "How many Orthodox Churches we have in Moldova?". Orthodoxia.md. Accessed October 29, 2021. http:/ / www.ortodoxia.md/2011/04/cate-biserici-ortodoxe-avem-inmoldova/.

- Pârlog Nicu. 2012. Găgăuzii: rătăciți prin istorie (Gagauzians: lost though history). Accessed October 2021. http://www.descopera.ro/cultura/9145873-gagauzii-rataciti-prin-istorie.

- Poenaru, Florin. 2012. Republica Moldova: complexul de superioritate al României (The Republic of Moldova: the superiority complex of Romania). Accessed September 29, 2021. http://www.criticatac.ro/18342/republicamoldova-ca-sindrom/.

- Stoica, Alina, Mircea Brie. 2010. "The Cultural frontiers of Europe. Introductory Study". The Cultural frontiers of Europe. Eurolimes. vol. 9: 5-8. edited by Alina Stoica, Didier Francfort, Judit Csoba Simonne. Oradea,.

- The Bible. Genesis. chpt. 11.

- Traci, Lilia. 2021. Serbia vrea să consolideze statutul 'alfabetului chirilic' şi identitatea națională, (Serbia wants to strengthen 'Cyrillic alphabet' status and national identity). AGERPRES. Accessed October 29, 2021. https://www.agerpres.ro/politic-ex/2021/09/15/serbia-vrea-saconsolideze-statutul-alfabetului-chirilic-si-identitatea-nationala--780150. 